UDC 101.1:316.4

\title{
INFORMATION RISKS IN THE DEVELOPMENT OF CONTEMPORARY SCIENCE
}

\author{
CT Tsyra, Oleksandra \\ Odessa National Academy of Telecommunications named after O. S. Popov, Educational and \\ Research Institute of Infocommunications and Software Engineering, the Department of \\ Communication Networks (Odesa, Ukraine) \\ E-mail: Kaphedra.philos@onat.edu.ua, ORCID 0000-0003-3552-2039
}

\begin{abstract}
The article explains the essence and architectonics of informatization and the constructivism of its impact on all spheres of social development. This process has contradictions related to the intensive development of new information technologies, modernization processes and their revolutionary influence on all spheres of public life. As a dialectical process, informatization is explained as a factor containing risks in the development of a scientific knowledge. These risks are associated with the informatization of the individual about the state of the information resources of science which generates the process of amplification of foundation of the development of various forms of extra-scientific knowledge. Risk is characterized as a share of "bad" in "good", it is associated with subjectivism and destructivism in the interpretation of true scientific knowledge, its use in selfish interests. In the information age, technological development has led to the fact that attention has shifted from objectives to means. Not the search for truth but the solution of the status problems became the main thing. Attention is focused on the specific weight of the development of quasi-science and anti-science which consciously distort the idea of science about the essence of natural and social reality. Pseudoscience is explained as an intellectual activity of the subject, imitating scientific activity and not bringing increments of a new objectively true knowledge. The attention is on the formation of the psevdoequivalence of subject which leads to his spiritual disintegration and the loss him capacity to discern truth. The process of strengthening information cynicism in the public consciousness which is formed by modern informatization processes is disclosed. Information cynicism is presented as a form of worldview reflecting a nihilistic attitude to info-resources and forming a mistrust of the truth of any information including science-based. And as a result there is a real threat of falsification and speculation on modern but not very productive areas.

Keywords: informatization, subject, risk, knowledge, extra-scientific knowledge, quasi-science, anti-science, pseudoscience, informational nihilism
\end{abstract}

\section{Introduction}

The deepening into the annals of the becoming of science as a specific kind of the spiritual activity of mankind asserts us in the thought about that this is due to the formation and development of two structures in one substratum. First, with the biological structure reflecting the emergence of the intellect in the biosphere, the mystery of which cannot be calculated rationally, for its development is predetermined not by rational causation, but by the Great Cosmos. Secondly, with the social structure which under the stage of its transition from barbarism to the civilizational stage in the history of mankind. This transition gave a violent impetus to the development of culture in the unity of its material and spiritual components. An analysis of the development of the science shows that on the basis of the movement of the inquisitive intellect of mankind in its content a complex of problems about the essence of nature, man and their interrelations was formed, which in their totality reflected the intellectual horizon of the corresponding type of civilizational structure of society.

The above problems are global in their formulation and essence. The science of both traditional and technogenic civilization throughout their being progressively revealed and deepened the content of these problems thus forming three branches of a scientific knowledge - natural science, humanitarian and technical. In the new hypostasis, science shapes its image and its social significance in the information civilization. Here it appears as a megatrend (USA), as a determinative Pillar (China) of the development of all spheres of the activities of society. However, to rely on the fact that science automatically solves all the problems that arise before society it is impossible. The development of modern science is a complicated and contradictory process it takes place transformations, fluctuations, risks caused by both internal processes of its (C) Tsyra Oleksandra, 2018 
development and globalization take place in it. Therefore, the appeal to explanation the risks in the development of a modern scientific knowledge, in conditions of exponential growth of the information and the informatization processes, is actual and necessary.

The analysis of the latest publications, in which this problem is examined, reflects the processes of the information society, its essence and role in the formation of the globolizing world. Here one can single out the works of R. F. Abdeev, V. G. Voronkova, P. A. Vodopyanov, A. I. Zelenkov, M. Yu. Maksimenyuk, M. V. Zarenin, V. L. Inozemtsev, N. N. Moiseev, V. A. Nikitenko, O. P. Punchenko, A. V. Sosnin, V. S. Stepin, A. D. Ursul, D. I. Shirokanov, V. Yu. Yakovets, and others. The cornerstone position in the concepts of these authors is the statement that this is the highest phase of the development of a postindustrial society which the processes of production, processing and transmission of information are recorded in various ways on carriers of any physical property and is designed to meet information needs and the subject and the society. From the standpoint of this approach to the analysis of the information society, V. G. Voronkova writes that "the concept of the information society reflects the growth of the role and importance of information in the life of society, of the production, dissemination and consumption of information as a socio-cultural and as a socioeconomic product ... The information society is a society in which information and the level of its use have a profound impact on economic development and socio-cultural changes in society "[1, p. 17]. Undoubtedly, in this society, computer technologies with their fundamental function of enhancing the intellectualization of human labor will be decisive and the leading role will belong to intellectual production, the core of which is science with its main task - the production of knowledge.

The aim of scientific research is to disclose informatization as a factor of risks in the development of modern science through analysis of concepts that reflect the objective progress of its development.

\section{Discussion of the problem}

The development of a modern scientific knowledge is the process is complex, contradictory, containing a number of risks. Before talking about that, it is necessary to turn to our understanding of science. However, even J. Bernal noted that it is difficult to give a definition of science, since it is practically impossible to take into account all of its hypostases in one definition. And in them science acts: as a system of knowledge; as an activity; as a social institution; as a subsystem of culture; as a productive force; as the basis of the innovation system; as a form of social consciousness. Nevertheless, in order to disclose the stated goal, it is necessary to propose a working definition of this socio-cultural phenomenon. Science is a historically developed and developing, socially-conditioned and systematically organized sphere of human activity for producing objective knowledge about natural and social reality. At the factor of objectivity of scientific knowledge was repeatedly pointed out by A. Einstein. A scientific knowledge in his opinion: "is a world of objective vision and understanding" [2, p. 9]. Scientists consciously strive to obtain an objective knowledge in order to "free themselves from the erratic goals of chance-personal understanding of the world" [2, p. 9].

But the translation and introduction into the consciousness of a person and society of objective scientific knowledge is the task of informatization processes. "Informatization", says A. A. Lazarevich, - "is a socially organized, purposeful process of information flow, based on the development of various methods and means of obtaining, transforming, storing and using it by various social subjects" [3, p. 180]. The process of informatization is very complex for its implementation it requires the development of information technologies that instrumentally provide for it. These technologies rely on advances in the field of computer technics and communications. They represent a totality of technical, program and organizational-economic means, combined structurally and fundamentally to solve a specific problem posed.

The architectonics of informatization is complex. She "as a process," notes O. P. Punchenko, "possesses a concept (known in advance initial information, expressed in categorical terms); structure that including in its content stable, relatively unaltered constant under all transformations of the system which constituent elements ... The structure acts as an integrating factor of the components of the informatization process and determines its quality "[4, p. 356]. As a sociocultural process, possessing essence, semantic load and social significance, informatization reflects the constructivism of influence on all social being. It affects the degree of development of the

Information risks in the development of contemporary science 
infrastructure of material and spiritual production; dramatically increases the sphere of market exchange; is the basis of transformation in the social structure; in the formation of a new world order and management it, satisfies a person and society in information needs.

Nevertheless, the processes of informatization about the achievements of scientific knowledge contain not only positive in the concerning the solution of the pressing problems of society, but also conceal a number of risks. "Risk," writes L. A. Sosnovsky, "is the expectation of disturbance in objects, systems, processes this is, in the generalized view, the expectation of any adverse phenomena, events, situations in nature and society. Quantitatively, such an expectation can estimated as the share of "bad" in "good" "[5, p. 68].

What risks are possesses the informatization process for the development of science? First of all, they are connected with the informatization of the individual about the state of the intellectual information resources of science, with the cumulative social intelligence as a whole. Personality uses this information to solve specific individual problems. But this information can be used in both positive and negative aspects. In the second aspect, there are arise risks of subjective interpretation of the objective nature of scientific knowledge and, on this basis of the foundation of one of the varieties of an extra-scientific knowledge. There are risks of strengthening quasi-science, pseudoscientific and antiscientific knowledge, as well as information cynicism. Also can talk about the risks of developing other forms of the extra-scientific knowledge, but the abovementioned constitute its core. Therefore, one of the main tasks of modern science is to justify the demarcation line between objective and subjective "scientific character", between its essence and the extra-scientific knowledge, which "we will understand as a knowledge that does not have (at least partially) attributive parameters of scientific knowledge" [6, p. 30].

The extra-scientific forms of the spiritual exploration of the world exist and develop thanks to the development of science and, moreover, strive to use of it principles of organization and an instruments, duplicate of it social functions and often do not openly opposes science, mimic for it claiming solutions to the priority problems of science. This is the risk of developing quasi-science, which is "a totality of the different by the quality ways of spiritual exploration of reality, competing with science for spiritual leadership in the sphere of public consciousness and which actively imitating its intellectual technologies" [7, p. 235]. And the question arises: what are the reasons for the increase in the specific weight of quasi-science in the conditions of the development of the science of information society? Researchers of this process note the following: "the negative consequences of scientific and technological progress; the inadequate high cost of a number of scientific projects (primarily research in the field of space and high-energy physics); a constant increase of the barrier that divides the scientific-technical and humanitarian intelligentsia, because the degree of abstraction of theoretical knowledge is constantly growing and the experimental toolkit of science is becoming more complicated "[7, p. 235].

The specificity of being of quasi-science is that this kind of the extra-scientific knowledge creates the basis for the development of the pseudoscientific knowledge on the one hand and on the other this knowledge "seeks supporters and adherents, relying on methods of violence and coercion. It, as a rule, blossoms in the conditions of rigidly hierarchical science, T. G. Leshkevich notes, - where it is impossible to criticize the power of those who hold it that be where the ideological regime is strictly manifested "[8, p. 304]. In the history of the development of science, it is possible to single out periods of triumph of quasi-science: cybernetics (in the management of social and technical systems); genetics (in biology); fixism (in geology); semiotics (in philosophy); darwinism (in biology), etc.

To the risk in the development of scientific knowledge the development of antiscientific knowledge is necessary to include. This kind of knowledge deliberately distorts the notion of science about the essence of natural and social reality. It is based on two postulates. First, his methodology in the construction of the future social reality is Utopian knowledge, which does not take into account the regularities of social development, acting as an illusory rosy development of the future society. But these ideas did not work either for Cigarelli (XIV century, Italy), nor for T. Mor (XVI century, England), nor for T. Campanella (XVII century, Italy), nor for Morelli, but also for representatives of critical utopian socialism Saint-Simon, Sh. Fourier (XVII-XVIII century), Owen.

Secondly, the antiscientific approach denies the basic principles, the regularities of the 
development of science. It is typical for him to rely on those problems that are difficult to prove in the structure of scientific knowledge and this serves as a basis for refuting the objectivity of scientific knowledge. This methodological solipsism in explaining the essence of development of nature, society, cognitive processes is the basis of various concepts of antiscientific knowledge. A particularly dangerous risk for the increment of a new - truly objective knowledge, that arises with the unfolding development of the pseudoscientific knowledge. This type of the unscientific knowledge represents "is an intellectual activity that profiteers on a set of popular theories" [8, p. 305]. For this type of the knowledge the informatization appears as the alpha and omega of it modern being, that contains many factors that support it growth. In the sea of scientific information pseudo-scientist finds what brings him benefit, fame and satisfies his ambitions. He is an intellectual because he is involved in the processing of a large body of information, but this activity only imitates the scientific, it is not so in essence and in result.

The development of the pseudoscience brings of the society double damage: first, based on the methodological tools of modern science, this kind of the extra-scientific knowledge does not enrich science, does not bring it dividends in the form of incremental objective knowledge where the activity of a pseudo-scholar demonstrates the poverty of his scientific creativity; secondly, very often pseudo-scientists have real scientific degrees, academic titles and buying for money the articles, monographs, dissertations which satisfying their conformist ambitions. These ambitions are characterized by adaptability, the lack of their own abilities to grow scientific knowledge and which not constructively use criticism as a form of the movement of thought in analyzing and refining the process of development of scientific achievements.

The study of the semantic "loading" of pseudoscientific knowledge shows that "pseudoscience as a form of imitation of science, - notates O. P. Punchenko, - is justified by the pseudo-scientists as a form of the scientific knowledge and this is not a deviation - it is a self-sufficient whole that functions outside science as an independent education such as mythology or religion. The property to function independently of the substance that generates it is a characteristic feature of pseudoscience " $[9$, p. 207].
What is acting by the theoreticalmethodological and socio-psychological prerequisites for the formation and dissemination of pseudoscientific knowledge? First of all, the illegitimacy of the presentation of complex scientific ideas, their subjective interpretation, which does not correspond to the level of scientific achievements, "completion" of these ideas without reliance on existing instrumental models. This is in the first place. Secondly, parasitizing on the insufficiency of the scientific knowledge, laws, principles and processes in proving the truth of a particular problem, on the part of a pseudo-scientist. Thirdly, pseudoscience is characterized by sensationalism, infallibility, the methodology of research that is opened as a personal interpretation of the problem, the use of a categorical apparatus and vocabulary incomprehensible to the audience with which the pseudo-scientist works. $\mathrm{He}$ circumvents problems that are not confirmed by scientific practice, his task is to convince people of the truth of his ideas while he relies on the ordinary level of their consciousness.

As an instrument, he uses the media, which actively and closely with him interacts for the sake of material gain. This "union" can be described as a form of deception of the population, extortion, for the sake of selfinterest, as a pseudo-scholar, and the media. The development of pseudoscience is promotes by holding conferences, the printing of a large number of articles, theses whose effectiveness is zero, which have no scientific value and novelty, and which only imitate science. Thus, subjectivism and pseudoscience in the presentation of complex scientific ideas to their complete misunderstanding for the addressee, sensationalism, of appeal to ordinary consciousness and the "authority" of the pseudoscientist, the departure from the explanation of acute problems in the cognition the natural and social reality - this is a methodological, epistemological, and social the basis of this kind of extra-scientific knowledge, increasing the risks of chaos in the ocean of scientific knowledge.

One of the informatization risks is the formation of the information cynicism of the cognizing subject. Cynicism, as a form of worldview, reflects a nihilistic attitude to the information that the media represent, especially the Internet. The falsity of information disseminated by the Internet has been repeatedly criticized even at the level of heads of state.

Information risks in the development of contemporary science 
Thus, addressing the people on April 21, 2016, President of Belarus A. G. Lukashenko demanded to sort out the information on the Internet, since the truth in it is few. Undoubtedly, the information on the Internet "works" today on the sphere of everyday consciousness of society and the individual, it is a great tool for the formation of information cynicism, as a lack of faith in the truth of any information, also including scientific evidence. If cynicism, in the opinion of P. Sloterdijk, is the dusk of a false consciousness, and information cynicism appears as an "enlightened false consciousness", "it exists as a fundamental setting of the individual, corresponding to the state of things in world ... He puts himself in tactful forms ..., tactfulness - this is the key word used that to gracefully say about alienation "[10, p. 36].

Informatization promotes the formation of a cynic of a mass type, which averaging the social character in society. "The modern cynic is an antisocial type integrated into society that is able to compete with regard to the latent lack of illusions ... After all, we are talking about the position of people who have clearly understood for themselves that the time of naivety have passed" [10, p. 32]. For a subject who allows to be informed comprehensively, over time everything becomes indifferent, because he does not see ways to solve of the problem that corresponding to his life credo, to the structures of his thinking. Pseudoequivalence is formed in him, which leads him to spiritual disintegration and indifference, to a loss of ability to distinguish truth from falsehood, essence from the phenomenon, constructive from destructive. This pseudoequivalence is the basis for the formation of the cynicism of the subject, which is formed by modern informatization processes.

\section{Conclusions}

Thus, along with the great positive of constructivism of informatization in the life of society, the article reveals the risks arising in science due to the information-awareness of the subject about problems which it solves. These risks are revealed through the formation and development of various systems of the extrascientific knowledge, in particular quasisciences, anti-science, pseudoscience, which destructively reflect the process of development of scientific knowledge, speculate on the difficulties of an objective solution of a number of problems, concerning the essence of natural and social reality, ambitious and material nature. As a special risk of the informatization process highlighted the formation of the information cynicism of the subject of modern civilization.

Prospects for further research: to reveal the essence and reasons for the formation of the information cynicism in science and the forms of its manifestation.

\section{Список використаних джерел}

1. Воронкова В. Г. Філософія інформаційно-комунікативного суспільства: теоретикометодологічний контекст. Запоріжжя: ЗДІА, 2016. 276 с.

2. Эйнштейн А. Принципы научного исследования // Физика и реальность. М: Наука, 1965. 360 с.

3. Лазаревич А. А. Становление информационного общества. Минск: Беларуская наука, 2015. 537 с.

4. Пунченко О. П. Цивилизационное измерение истории человечества. Одесса: Астропринт, 2013. $448 \mathrm{c}$.

5. Сосновский Л. А. Риск. Золотое сечение. Гомель: УО «Белгут», 2004. 317 с.

6. Ратніков В. С. Основи філософії науки і філософії техніки. Вінниця: ВНТУ, 2012. 291 с.

7. Яскевич Я. С., Лукашевич В.К. Философия и методология науки. Минск: БГЭУ, 2009. 475 с.

8. Лешкевич Т. Г. Философия и теория познания. М.:ИНФРА-М, 2013. 408 с.

9. Пунченко О. П. Информатизация как фактор риска в развитии современного научного познания // В кн.: Диалог культур в эпоху глобальных рисков. Минск: РИВШ, 2016. 236 с.

10. Слотердайк П. Критика цинического разума. Екатеринбург: У-Фактория, 2009. 800 с.

\section{REFERENCES}

1. Voronkova, V. G., Sosnin, O.V., Nikitenko, V.O., Maksimenyuk, M.Yu. (2016). The phylosophy of the informational-communicative society: theoretical and methodological context. Zaporizhzhia: ZSEA. 276 s. [in Ukrainian].

2. Einstein, A. (1965). Principles of scientific research // Physics and Reality. M: Science. 360 s. [in Russian].

3. Lazarevich, A. A. (2015). The becoming of the Information Society. Minsk: Belarusian Science. 537 s. [in Russian].

4. Punchenko, O. P. (2013). Civilizational Dimension of the History of Humanity. Odessa: Astroprint. 448 s. [in Russian].

5. Sosnovsky, L. A. Risk. (2004). The Golden Section. Gomel: EI "Belgut". 317 s. [in Russian]. 
6. Ratnikov, V.S. (2012). Fundamentals of the Philosophy of Science and Philosophy of Techniques. Vinnitsa: VNTI. 291 s. [in Ukrainian].

7. Yaskevich ,Ya. S., Lukashevich V.K. (2009). Philosophy and Methodology of Scienceю Minsk: BSEU. 475 s. [in Russian].

8. Leshkevich, T. G.(2013). Philosophy and theory of knowledge. M.: INFRA-M. 408 s. [in Russian].

9. Punchenko, O. P. (2016). Informatization as a risk factor in the development of the modern scientific knowledge // In book: Dialogue of Cultures in the Era of Global Risks. Minsk: RIVSCH. 236 s. [in Russian].

10. Sloterdijk, P. (2009). Criticism of cynical reason. Ekaterinburg: U-Faktoriya. 800 s. [in Russian].

Цира О. В. - Одеська національна академія зв'язку ім. О. С. Попова (Одеса, Україна), E-mail: kaphedra.philos@onat.edu.ua, ORCID 0000-0003-3552-2039

\section{ІНФОРМАЦИЙНІ РИЗИКИ У РОЗВИТКУ СУЧАСНОЇ НАУКИ}

\section{Анотація.}

У статті пояснена сутність і архітектоніка інформатизації, конструктивізм іï впливу на всі сфери суспільного розвитку. Цей процес має суперечності, зв'язані 3 інтенсивним розвитком нових інформаційних технологій, процесами модернізації та їх революційним впливом на всі сфери суспільного життя. .Як діалектичний процес інформатизація пояснена як фактор, що містить ризики в розвитку наукового знання. Ці ризики пов'язані з інформатизацією особистості про стан інформаційних ресурсів науки, що породжує процес посилення фундування розвитку різних форм позанаукового знання. Ризик охарактеризований як частка «поганого» в «хорошому», він пов'язаний з суб'єктивізмом та деструктивізмом в трактуванні істинно наукового знання, використанням його в корисливих інтересах. В інформаційну епоху технологічний розвиток призвів до того, що увага переключилась 3 цілей на засоби. Не пошук істини, а рішення статусних проблем стало головним. Акцентовано увагу на питомій вазі розвитку квазінауки та антинауки, котрі свідомо спотворюють уявлення науки про сутність природної та соціальній реальності. Псевдонаука пояснена як інтелектуальна активність суб'єкта, що імітує наукову діяльність і не приносить збільшення нового об'єктивно істинного знання. Акцентовано увагу саме на формуванні псевдоеквівалентності суб'єкта, що призводить до його духовної дезінтеграції та втрачанню ним можливостей відрізняти істину. Розкривається процес посилення інформаційного цинізму в суспільній свідомості, який формується сучасними процесами інформатизації. Інформаційний цинізм представлено як форму світогляду, що відображає нігілістичне відношення до інфоресурсів та формує недовіру до істинності будь-якої інформації, в тому числі і науково-обгрунтованої. І як результат виникає реальна загроза фальсифікацій та спекуляцій на сучасних, але мало продуктивних напрямках.

Ключові слова: інформатизація, суб'єкт, ризик, знання, позанаукові знання, квазінауки, антинауки, псевдонаука, інформаційний нігілізм.

\section{Цыра A.B. - Одесская национальная академия связи им. А. С. Попова (Одесса, Украина) E-mail: Kaphedra.philos@onat.edu.ua, ORCID 0000-0003-3552-2039 ІНФОРМАЦИОННЫЕ РИСКИ В РАЗВИТИ СОВРЕМЕННОЙ НАУКИ}

\section{Аннотация.}

В статье объяснена сущность и архитектоника информатизации, конструктивизм ее влияния на все сферы общественного развития. Этот процесс имеет противоречия, связанные с интенсивным развитием новых информационных технологий, процессами модернизации и их революционным влиянием на все сферы общественной жизни. Как диалектический процесс, информатизация объясняется как фактор, который имеет риски в развитии научного знания. Эти риски связанные с информатизацией личности о состоянии информационных ресурсов науки, которая рождает процесс усиления фундирования развития разных форм вненаучного знания. Риск характеризуется как результат «плохого» в «хорошем», он связан с субъективизмом и деструктивизмом в понимании истинно научного знания, использованием его в корыстных целях. В информационную эпоху технологическое развитие привело к тому, что внимание переключалось с целей на средства. Не поиск истины, а решение статусных проблем стало главным. Акцентировано внимание на удельном весе развития квазинауки и антинауки, которые сознательно извращают представления науки о сущности природной и социальной реальности. Псевдонаука представлена как интеллектуальная активность субъекта, который имитирует научную деятельность и не приносит увеличения нового объективно истинного знания. Акцентировано внимание на формировании псевдоэквивалентности субъекта, который приводит к его духовной дезинтеграции и потере им возможностей отличать истину. Раскрывается процесс усиления информационного цинизма в общественном сознании, который формируется современными процессами информатизации. Информационный цинизм представлено как форму мировоззрения, которое отражает нигилистическое отношение к инфоресурсам и формирует недоверие к истинности любой информации, в том числе и

Information risks in the development of contemporary science 
научно-обоснованной. И как результат возникает реальная угроза фальсификаций и спекуляций на современных, но мало продуктивных направлениях.

Ключовые слова: информатизация, субъект, риск, знание, вненаучные знания, квазинауки, антинауки, псевдонаука, информационный нигилизм.

Стаття рекомендована до публікачії д.філософ.н., проф. В.Г. Пунченко О.П. (Одеса, Украӥна) Надійшла до редколегіï: 01.03.2018 p. Прийнята до друку: 05.03.2018p.

Цира Олександра Василівна, кандидат філософських наук, викладач кафедри Мереж зв'язку Одеської національної академії зв’язку ім. О. С. Попова (Одеса, Україна), вул. Ковальська, 165029 Одеса Україна

E-mail: Kaphedra.philos@ onat.edu.ua, ORCID 0000-0003-3552-2039 